\title{
THE LEGAL STATUS OF REFUGEE PROTECTION AND STATE OBLIGATIONS IN UGANDA
}

\author{
Ahimbisibwe Frank ${ }^{*}$
}

Uganda is a host country to refugees from neighboring countries affected by conflicts and war. According to UNHCR, by the end of 2015, Uganda was the 8th and 3rd top refugee hosting country in the world and Africa respectively. It hosted around 512,968 refugees. Uganda was estimated to host around 810,000 refugees by the end of 2016. This raises the questions that as one of the top refugee hosting countries; are refugees legally protected in Uganda? What are the gaps existing in this legal framework? What legal obligations does Uganda have in refugee protection? This paper answers these questions by analyzing the existing refugee and human rights legal instruments to which Uganda is a signatory. The paper further makes reference to case law as evidence that states have obligations to protect refugees. In analyzing the legal framework, the existing gaps are identified. This paper argues that refugees in Uganda are protected by both refugee and human rights law. Refugee law protects refugees by virtue of their status as refugees who have crossed international borders and in need of international protection. Refugees are also protected by human rights law as individuals and human beings regardless of their status as refugees or aliens and wherever they have gone. Courts' jurisprudence has confirmed that states have obligations to protect refugees.

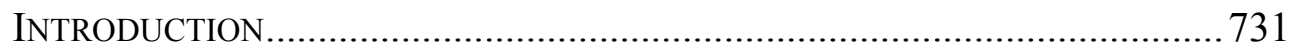

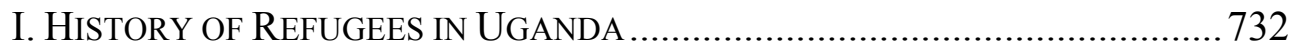

II. INTERNATIONAL REFUGEE LAW PROTECTION FRAMEWORK ...................735

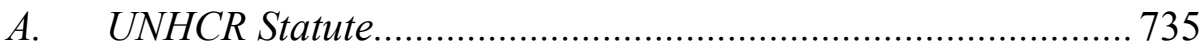

B. $\quad 1951$ UN Convention Relating to the Status of Refugees .........736

C. 1967 Protocol Relating to the Status of Refugees ......................739

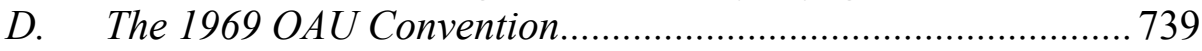

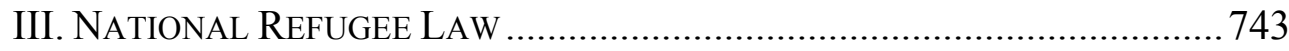

A. 2006 Uganda Refugees Act............................................... 743

B. $\quad$ Refugee Rights under the Act................................................. 743

C. Duties and Obligations of Refugees under the Act.................. 744

\footnotetext{
* BA, MA, Ph.D., Scholar in Residence, Institute of Development Policy and Management, University of Antwerp, Belgium; Senior Lecturer, Mbarara University of Science and Technology \& Kampala International University, Uganda. Research fields: Refugee Studies, Security Studies and Human Rights. This article is an updated version of a chapter in my PhD thesis. I am indebted to my supervisor, Prof. Filip Reyntjens for his mentorship. I also thank the anonymous referees for their useful comments. Mistakes and omissions remain mine. I acknowledge the financial support of DAAD, VLIR-UOS, NUFFIC and Mbarara University of Science and Technology towards my Ph.D. studies.
} 


\section{THE LEGAL STATUS OF REFUGEE PROTECTION 731}

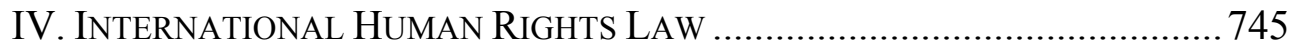

A. Universal Declaration of Human Rights ................................ 746

B. International Covenant on Civil and Political Rights ............... 747

C. International Covenant on Economic, Social and Cultural Rights

D. International Convention on the Elimination of All Forms of

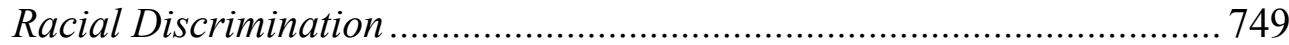

E. Convention against Torture and Other Cruel, Inhuman or

Degrading Treatment or Punishment..................................................... 750

F. Convention on the Rights of the Child ..................................... 751

$G$. Convention on Elimination of All Forms of Discrimination

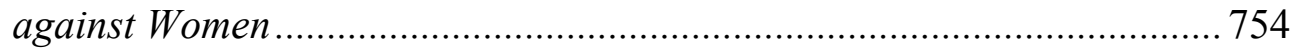

H. African (Banjul) Charter of Human and Peoples' Rights ........756

I. African Charter on Rights and Welfare of the Child................ 757

J. Protocol to the African Charter on Human and Peoples' Rights

on the Rights of Women in Africa 759

V. NATIONAL HUMAN RIGHTS LAW ………............................................ 760

A. 1995 Uganda Constitution...................................................... 760

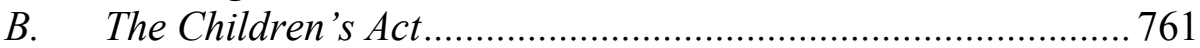

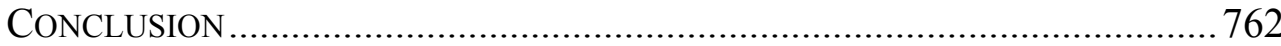

\section{INTRODUCTION}

By September 2016, Uganda was host to around $700,000^{1}$ from mainly neighboring countries of South Sudan, Democratic Republic of Congo, Burundi, Rwanda and Somalia among others. ${ }^{2}$ Uganda is a party to international refugee and human rights law. Uganda has also enacted the 2006 Refugees Act and other domestic human rights laws including the 1995 Constitution and Children's Act. All these are aimed at protecting the rights of refugees and nationals. "Under international law the government has a duty to ensure that the rights of refugees under those treaties are promoted, protected and fulfilled, where necessary".3

This paper analyzes the existing refugee and human rights legal instruments to which Uganda is a signatory. The paper points out the status

\footnotetext{
${ }^{1}$ Lule Jeff Andrew, Uganda Now Hosts More Than 700,000 Refugees, NEw Vision, available at http://www.newvision.co.ug/new_vision/news/1435630/uganda-hosts-700-refugees (last visited September 19, 2016).

${ }^{2}$ The paper gives a history of refugees from these countries to Uganda in the next section below.

${ }^{3}$ Vienna Convention on the Law of Treaties, 1969, quoted by Mujuzi, Jamil Ddamulira, From Archaic to Modern Law: Uganda's Refugees Act 2006 and Her International Treaty Obligations, 14 (2) East African Journal of Peace And Human Rights 399— 422 (2008).
} 
of refugee protection and state obligations under refugee and human rights law. It also points out the gaps in the legal framework. The paper further makes reference to case law as evidence that states have obligations to protect refugees. The author starts with refugee law followed by human rights law. In both cases, the author looks at national, regional and international legal instruments. This paper makes the case that refugees in Uganda are protected by both refugee and human rights law. Refugee law protects refugees by virtue of their status as refugees who have crossed international borders and in need of international protection. Refugees are also protected by human rights law as individuals and human beings regardless of their status as refugees or aliens and wherever they have gone. ${ }^{4}$ Refugee and human rights law also provides for state obligations towards refugees. In the next section, the paper briefly looks at the history of refugees in Uganda.

\section{HISTORY OF REFUGEES IN UGANDA}

Uganda's experience with refugees started during the Second World War when Europeans displaced by the war were settled on its territory. ${ }^{5}$ These refugees included 7,000 prisoners of war mainly from Poland but also from Germany, Romania and Austria among others. They were settled at Nyabyeya in the present day Masindi district and Kojja (Mpunge) Mukono district. This influx was soon followed by numerous refugees generated by unrest in the aftermath of the various struggles for independence in neighboring countries. ${ }^{6}$

Gingyera and Pirouet observe that the new wave of refugees into Uganda came in 1955 from the then Anglo-Egyptian Condominium of the Sudan. The Anyanya movement that involved South Sudanese fighting for self-determination led Sudanese to cross into Uganda in search of refuge. Some 80,000 southern Sudanese crossed into Uganda after an army mutiny in Sudan. ${ }^{7}$ Most of them were settled in West Nile in North Western Uganda.

\footnotetext{
${ }^{4}$ Amnesty International, Rights Wherever You Are, (AI-index: POL 33/001/2002, 2002), November 4, quoted by Liv Halperinn, The Physical Security of Refugees in Kenyan Camps, Legal and Human Rights Implications, MA Dissertation, Tufts University, Unpublished, available at http:fletcher.tufts.edu (last visited September 26, 2013).

${ }^{5}$ Gingyera Pinycwa (ed.), Uganda and the Problem of Refugees, at 5 (Kampala: Makerere University 1998).

${ }^{6} \mathrm{Ibid}$, at 5 .

${ }^{7}$ L. Pirouet, Refugees in and from Uganda in the Post Colonial Period, In UGANDA Now, BETwEEN Decay and Development (M. Twaddle and H. B. Hansen eds., Nairobi: Heinemann Publishers, 1988) quoted by Mulumba Deborah \& Wendo Mlahagwa Olema, Policy Analysis Report: Mapping Migration in Uganda, at 10 (September 18, 2009), available at http://www.immis.org/wpcontent/uploads/2010/05/Policy-Analysis-Report-Uganda.pdf (last visit June 30, 2013).
} 


\section{THE LEGAL STATUS OF REFUGEE PROTECTION 733}

Following the 1972 Addis Ababa Agreement, the Sudanese refugees were repatriated. However, the Sudanese influx resumed from 1983 to 2005 when the Sudanese People's Liberation Army/Movement (SPLA/M) were engaged in armed rebellion against the Khartoum Government. The majority started to return to South Sudan in 2005 after the signing of the Comprehensive Peace Agreement (CPA). A new influx of South Sudanese refugees took place from December 2013 when fighting broke out in South Sudan between the Government and the opposition. South Sudanese have continued to flee into Uganda since.

In the 1950s, Kenyans staged an armed rebellion against the British colonial government. The colonial government ruthlessly suppressed the armed Mau anti colonial movement. A number of Kenyans fled into Uganda as refugees. Kenya again generated refugees in 2007/2008 due to violence following the 2007 elections. They crossed into Eastern Uganda and were hosted in refugee settlements while others were self settled in urban areas.

The political turmoil in Rwanda forced Rwandan Tutsi to flee the country in 1959 and early 1960s. They fled into neighboring countries Uganda, Tanzania, Congo and Burundi. They were allocated pastoral land and settled in Nakivale, Oruchinga in Mbarara District (now Isingiro district). Others were settled in Rwamwanja, Kyaka and Kamwengye in Kyenjojo and Kabarole districts. ${ }^{8}$ However, although majority of Rwandan refugees repatriated in 1994 after the genocide and the taking over of the Rwandan government by the Rwandan Patriotic Army, many still maintain relatives and property in Uganda. ${ }^{9}$

In 1994 and after the Tutsi refugees returned to Rwanda, Hutu refugees crossed into Uganda, DRC, Tanzania and Burundi. According to UNHCR by February 2016, there were 17,176 Rwandan refugees in the country. ${ }^{10}$ Rwandan refugees are settled in Nakivale, Oruchinga, Kyaka II and Kyangwali refugee settlements in Uganda. Other Rwandan refugees are secondary movers - those that came from neighboring countries such as Tanzania and Democratic Republic of Congo (DRC) following the forced repatriations of 1996/1997, and who faced persecution upon return because of their previous flight and then fled to Uganda. ${ }^{11}$ Rwandan asylum seekers

\footnotetext{
${ }^{8}$ Mulumba Deborah \& Wendo Mlahagwa Olema, Policy Analysis Report, Op. Cit., at 10.

${ }^{9}$ Ibid.

${ }^{10}$ UNHCR, Uganda-Monthly Refugee Statistics Update, February 2016, available at data.unhcr.org/drc/download.php?id=1216 (last visit September 22, 2016).

${ }^{11}$ Karooma, Cleophas, Reluctant to Return? The Primacy of Social Networks in the Repatriation of Rwandan Refugees in Uganda, Working Paper Series No. 103, Refugee Studies Centre, University of Oxford, at 11 (August, 2014).
} 
(both Hutu and Tutsi) continue to come to Uganda claiming persecution, human rights violations and dictatorship in Rwanda. ${ }^{12}$

The conflicts in Zaire/DRC in the 1950s and 1960s in the aftermath of Independence and Lumumba's assassination in 1961 forced thousands of Congolese to flee into Uganda. Many of them were settled in Kyaka 1 in present day Kyenjojo district. Although around 2000 the UNHCR and the Ugandan government implemented a repatriation programme for Congolese refugees, many more Congolese refugees have fled into Uganda due to the conflicts in the Eastern part of the country. By the end of 2015, Uganda was home to around 201,800 Congolese refugees. ${ }^{13}$

Since the 1990s, the country also received a number of refugees from Burundi, Somalia, Ethiopia, Eritrea, and Kenya. According to Uganda's settlement policy, refugees are required to live in settlements where they can be assisted. However, a good number of refugees live in urban areas where they are required to look after themselves without any assistance from the UNHCR and her implementing partners.

According to the UNHCR's annual Global Trends report, by the end of 2015, Uganda was hosting more than 512,968 refugees and asylum-seekers, the highest number in the country's history. Uganda has now become the 8th-largest refugee hosting country in the world and the third largest refugee-hosting country in Africa. ${ }^{14}$ This number has increased to more than 700,000 with the addition of more than 230,000 South Sudanese refugees following renewed fighting in South Sudan in 2016. ${ }^{15}$ Uganda was estimated to host 810,000 refugees by the end of $2016 .{ }^{16}$ Uganda as a host country has obligations of protecting these refugees living on its territory. These obligations are derived from international refugee and human rights law which Uganda has ratified. Uganda has also enacted the 2006 Refugees Act and other domestic human rights laws including the 1995 Constitution and Children's Act. The paper now turns to the analysis of the legal framework for the protection of refugees.

\footnotetext{
${ }^{12}$ Rwandan asylum seekers include government officials, genocide survivors, journalists, students together with ordinary people.

${ }^{13}$ UNHCR, Global Trends: Forced Displacement in 2015, Geneva, UNHCR: 17, available at http://www.unhcr.org/576408cd7 (last visit September 19, 2016).

${ }^{14} \mathrm{Ibid}$, at 16.

${ }^{15}$ Lule Jeff Andrew, Uganda Now Hosts More Than 700,000, Op. Cit.

${ }^{16}$ See President of Uganda's Statement at the Leaders Summit on Refugees at the United Nations General Assembly, New York on September 20 2016, available at https://www.yowerikmuseveni.com/presidents-statement-leaders-summit-refugees-un-generalassembly-new-york (last visit October 4, 2016).
} 


\section{THE LEGAL STATUS OF REFUGEE PROTECTION 735}

\section{INTERNATIONAL REFUGEE LAW PROTECTION FRAMEWORK}

\section{A. UNHCR Statute}

In the aftermath of World War II, the United Nations General Assembly created the Office of the United Nations High Commissioner for Refugees (UNHCR) and consequently the UNHCR Statute ${ }^{17}$ hereinafter referred to as "the Statute". In resolution 319 (iv) of 3 December 1949, the United Nations General Assembly decided to establish a High Commissioner's Office for Refugees as of 1st January 1951.

The Statute of the Office of the United Nations High Commissioner for Refugees was adopted by the General Assembly on 14 December 1950 as Annex to Resolution 428 (V). In this Resolution, the Assembly also called upon the Governments to cooperate with the High Commissioner in the performance of his or her functions concerning refugees falling under the competence of the Office. In accordance with the Statute, the work of the High Commissioner is humanitarian and social and of an entirely nonpolitical character. $^{18}$

The mandate of UNHCR, based on its Statute, is to provide international protection to refugees who fall within the scope of the Statute and seek durable solutions for the problem of refugees. ${ }^{19}$ Within its mandate as stipulated in the Statute and subsequent General Assembly resolutions, UNHCR undertakes wide ranging protection and assistance activities, many of which relate directly or indirectly to the rule of law, for the purpose of enhancing the protection of refugees and other persons of its concern, including Internally Displaced Persons (IDPs) and returnees.

Uganda is a state party to the UNHCR statute and as a legal requirement she is bound by all the provisions of the statute. Under the UN General Assembly Resolution 428 (V) of 14th December 1950, states have obligations to cooperate with UNHCR by:

(a) Becoming parties to international conventions providing for the protection of refugees, and taking the necessary steps of implementation under such conventions;

(b) Entering into special agreements with the High Commissioner for the execution of measures calculated to improve the situation of refugees and to reduce the number requiring protection;

\footnotetext{
${ }^{17}$ UN, General Assembly Resolution 428 (V) of 14 December that gave effect to the UNHCR Statute (1950).

${ }^{18}$ Preamble to the UNHCR Statute.

${ }^{19}$ Article 1 of the UNHCR Statute.
} 
(c) Admitting refugees to their territories, not excluding those in the most destitute categories;

(d) Assisting the High Commissioner in his efforts to promote the voluntary repatriation of refugees;

(e) Promoting the assimilation of refugees, especially by facilitating their naturalization;

(f) Providing refugees with travel and other documents such as would normally be provided to other aliens by their national authorities, especially documents which would facilitate their resettlement;

(g) Permitting refugees to transfer their assets and especially those necessary for their resettlement;

(h) Providing the High Commissioner with information concerning the number and condition of refugees, and laws and regulations concerning them.

\section{B. 1951 UN Convention Relating to the Status of Refugees}

The 1951 UN Convention Relating to the Status of Refugees ${ }^{20}$ (hereinafter referred to as "The 1951 Convention") is the one truly universal instrument setting out the baseline principles on which the international protection of refugees has to be built. It is the foundation and cornerstone of refugee protection and places the responsibility for protecting refugees squarely on host states. It is the land mark in the setting of standards for the treatment of refugees. It incorporates either directly or as an inevitable interpretation the fundamental concepts of the refugee protection regime.

However, it should be noted that the 1951 Convention does not expressly provide for the right to security. It simply states in the preamble that "human beings shall enjoy fundamental rights and freedoms without discrimination". ${ }^{21}$ Failure to expressly provide a provision on the right of security definitely affects the responsibility of the host state towards these refugees.

The 1951 Convention establishes the essential minimum norms relating to the treatment of refugees. These norms must be applied without discrimination as to race, religion or country of origin. The 1951 Convention is the key legal document in defining who is a refugee, the rights of refugees and the legal obligations of state parties.

\footnotetext{
${ }^{20} \mathrm{UN}$, Convention Relating to the Status of Refugees, adopted on July 28, 1951 by the United Nations Conference of Plenipotentiaries on the Status of Refugees and Stateless Persons convened under General Assembly resolution 429 (V) of 14 December 14, 1950, entered into force April 22, 1954.

${ }^{21}$ Preamble of 1951 UN Refugee Convention.
} 


\section{THE LEGAL STATUS OF REFUGEE PROTECTION 737}

It spells out the kind of legal protection, other assistance and social rights a refugee should receive from the host state as well as a set of basic human rights (such as freedom of religion and movement, the right to work, education and accessibility to travel documents) which should for refugees be at least equivalent to freedoms enjoyed by foreign nationals. ${ }^{22}$

It is equally of great importance to note that the 1951 Convention defines refugee's obligations to host governments and indicates people or group of people who are not covered by the 1951 Convention such as war criminals (who do not qualify for refugee status).

Under the 1951 Convention, host governments are primarily responsible for the security and protection of refugees and state parties to this Convention are obliged to strictly carry out its provisions. The state parties agree to cooperate with UNHCR in its cardinal role that is the promotion of international agreements that provide for the protection of refugees and overseeing their application. ${ }^{23}$ The UNHCR can intervene if necessary to ensure that displaced people that fall under the definition of refugees are granted asylum and are not forcibly returned to countries where their lives are in danger.

The definition of a refugee according to the 1951 Convention ${ }^{24}$ stresses the insecurity that refugees face and the need for international protection in other countries. As James Darcy says, "It is the non-availability of effective national/domestic protection (when a country is unable or unwilling to protect its individuals), and the need for international protection, which is the main characteristic of a refugee". 25

The 1951 Convention, under Article 33(1), prohibits refoulement (that nobody should be forcibly returned to a country where his or her life or freedom would be at risk). To this end, it states as follows:

\footnotetext{
${ }^{22}$ Liv Halperin, The Physical Security of Refugees in Kenyan Camps, Legal and Human Rights Implications, MA Dissertation, Tufts University, unpublished (April 2003), available at http:fletcher.tufts.edu (last visit September 26, 2013).

${ }^{23}$ Article 35(1) of the 1951 Convention.

${ }^{24}$ Article 1(2) of the 1951 Convention defines a refugee as ". . . is a person, who, as a result of events occurring before 1 January 1951 and owing to well-founded fear of being persecuted for reasons of race, religion, nationality, membership of a particular social group or political opinion is outside the country of his nationality and is unable, or owing to such fear, is unwilling to avail himself of the protection of that country; or who, not having a nationality and being outside the country of his former habitual residence as a result of such events, is unable or owing to such fear, is unwilling to return to it".

${ }^{25}$ James Darcy, Human Rights and International Legal Standards: What do Relief Workers Need to Know, Relief And Rehabilitation Network, Paper No.19, at 27 (London: Overseas Development Institute, February, 1997), available at http://www.odi.org.uk/sites/odi.org.uk/files/odiassets/publications-opinion-files/2325.pdf.
} 
No Contracting State shall expel or return (refoul) a refugee in any manner whatsoever to the frontiers of territories where his life or freedom would be threatened on account of his race, religion, nationality, membership of a particular social group or political opinion.

It is equally important to note that the Government of Uganda acceded to the 1951 Convention on 27th September 1976 and thereby made a declaration in respect of Article 7 as follows:

In respect of Article 7: The Government of the Republic of Uganda understands this provision as not conferring any legal, political or other enforceable right upon refugees who, at any given time, may be in Uganda. On the basis of this understanding, the Government of the Republic of Uganda shall accord refugees such facilities and treatment as the Government of the Republic of Uganda shall in her absolute discretion, deem fit having regard to her own security, economic and social needs. ${ }^{26}$

Under Article 3 of the 1951 Convention, states have obligations to treat refugees the same way and should never discriminate against refugees on account of race, religion and nationality among other differentiations. In short, the 1951 Convention much as it outlines the rights of refugees (Articles 2-34), every refugee right is followed by an obligation of states. In fact the 1951 Refugee Convention is majorly concerned with refugee rights and the obligations of states. For every refugee right, there is a state obligation in the Convention.

However, one of the loop holes in the 1951 Convention is that it does not cater for persons escaping natural disasters and environmental hazards like volcanic eruptions, drought, earthquakes, famine and floods. These are common occurrences in Uganda and other African countries. These have led to forced displacement of people within and outside borders. With increased cases of environmental refugees due to climate change and other disasters, it is important that the United Nations amends the convention to protect people affected by environmental factors.

According to Makubuya, "one major problem with the Refugee Convention is its individualist approach. The Convention treats the refugee as an individual whose 'rights' must be protected and respected". ${ }^{27}$ Uganda as a host country has received and continues to receive large influxes of refugees from neighboring countries like South Sudan, DRC, Burundi, Rwanda and Somalia. In such large refugee influxes it is impractical to assess refugees on an individual basis. "The provisions of the Convention

\footnotetext{
${ }^{26}$ Adopted from http://www.refugeelawproject.org/ratifications.php.

${ }^{27}$ Makubuya Khiddu, The Legal Condition of Refugees in Uganda, 7(4) Journal of REFUGEeS STUDIES 409 (1994).
} 


\section{THE LEGAL STATUS OF REFUGEE PROTECTION 739}

do not translate easily into the actual protection of large numbers of people. One may need to think in terms of minimum standards for basic needs-food, shelter, clean water, sanitation, group rights and protection from inhuman and degrading treatment". ${ }^{28}$ In such cases, Uganda can only give prima facie refugee status to the refugees that had been not envisaged by the Convention.

\section{1967 Protocol Relating to the Status of Refugees}

The 1951 Convention could benefit only persons who had become refugees as a result of events occurring prior to 1 January 1951. However, the years following 1951 showed that refugee movements were not merely the temporary results of the Second World War and its aftermath. Throughout the late 1950s and 1960s new refugee groups emerged, in particular in Africa. These refugees were in need of protection which could not be granted to them under the limited time-frame of the 1951 Convention.

The 1967 Protocol Relating to the Status of Refugees (also referred to as "The 1967 Protocol") extended the application of the Convention to the situation of "new refugees", i.e. persons who, while meeting the Convention definition, had become refugees as a result of events that took place after 1 January $1951 .{ }^{29}$ Uganda acceded to this Protocol on 27 September $1976 .{ }^{30}$ Thus it can be asserted that the 1967 Protocol is an additional instrument, in form of amendment, which followed the 1951 Convention. It was intended to address the provisions in the 1951 Convention that were repugnant to the notion of human rights.

\section{The 1969 OAU Convention}

According to UNHCR "the 1951 Refugee Convention is 'the basic and universal instrument relating to the status of refugees', the OAU Convention is, to date, the only legally binding regional refugee treaty". "The 1969 Organization of African Unity Convention is a cornerstone of Africa's asylum policy going beyond the confines of the 1951 Convention and its Protocol, reflecting the hospitality of African governments towards the

\footnotetext{
${ }^{28}$ Ibid.

${ }^{29}$ UN Office of the High Commissioner for Human Rights, Fact Sheet No.20, Human Rights and Refugees, July, No. 20 (1993), available at http://www.refworld.org/docid/4794773f0.html (last visit May 20, 2014).

${ }^{30}$ UNHCR, Submission by the UNHCR for the Office of the High Commissioner for Human Rights' Compilation Report-Universal Periodic Review: Uganda, March: 1(2011), available at http://www.refworld.org/pdfid/4d806bc112f.pdf (last visit July 20, 2012).

${ }^{31}$ UNHCR, Refugee Protection: A Guide to International Refugee Law (December 1, 2001), available at http://www.refworld.org/docid/3cd6a8444.html (last visit September 25, 2013).
} 
continent's refugees", 32

More interesting is that the 1969 OAU Convention not only broadens but also reformulates the definition of a refugee. In Article 1(2) it adds the provision that:

The term refugee shall also apply to every person who, owing to external aggression, occupation, foreign domination or events seriously disturbing public order in either part or whole of his country of origin or nationality, is compelled to leave his place of habitual residence in order to seek refuge in another place outside his country of origin or nationality.

This broader definition of a refugee hence recognizes the legitimacy of flights in situations of generalized danger not limited to individual persecution. The 1969 OAU Convention states that "member states of the OAU shall, use their best endeavors to receive refugees". ${ }^{33}$ This therefore implies that states have the obligation to grant asylum to those that qualify for refugee status under the Convention. This is in line with the 1948 Universal Declaration of Human Rights which grants the right to seek and enjoy in other countries asylum from persecution. ${ }^{34}$ The 1969 OAU Convention has a similar article like the 1951 Convention, prohibiting refoulement, Article 2(3).

The principle of non-refoulement reflects the concern and commitment of the international community "to ensure to those in need of protection the enjoyment of fundamental human rights, including the right to life, to freedom from torture or cruel inhuman or degrading treatment or punishment and to liberty and security of person". ${ }^{35}$ According to the UNHCR "the principle of non-refoulement applies to not only to recognized refugees, but also to those who have not had their status formally declared. The principle of non-refoulement is of particular relevance to asylum seekers. As such persons may be refugees, it is an established principle of international refugee law that they should not be returned or expelled pending a final determination of their status". ${ }^{36}$

\footnotetext{
${ }^{32}$ Statement by Sadako Ogata, United Nations Higher Commissioner for Refugees and Salim Ahmed Salim, Secretary General, Organization for African Unity, OAU/UNHCR, Regional meeting on Refugee Issues in the Great Lakes, Kampala (May 9, 1998), available at http://www.unhcr.org/3ae68fcc30.html (last visit August 10, 2012).

${ }^{33}$ Article 2(1) of the 1969 OAU Convention.

${ }^{34}$ Article 14(1) of UDHR states that "everyone has the right to seek and to enjoy in other countries asylum from persecution."

${ }^{35} \mathrm{UN}$, Note on International Protection, Executive Committee of the High Commissioner's Programme, Session 44, A/AC.96/815, August 31, para. 10 (1993).

${ }^{36}$ UNHCR, Advisory Opinion on the Extraterritorial Application of Non-Refoulement Obligations under the 1951 Convention Relating to the Status of Refugees and its 1967 Protocol, Geneva, UNHCR, at 2-3 (at January 26, 2007), available at http://www.refworld.org/pdfid/45f17a1a4.pdf (last visit May 23, 2014).
} 


\section{THE LEGAL STATUS OF REFUGEE PROTECTION 741}

According to UNHCR "This has been reaffirmed by the Executive Committee of UNHCR, for example, in its Conclusion No. 6 (XXVIII) 'Non-refoulement' (1977), para. (c) (reaffirming 'the fundamental importance of the principle of non-refoulement ... of persons who may be subjected to persecution if returned to their country of origin irrespective of whether or not they have been formally recognized as refugees", 37

This same view is shared by Goodwin-Gill, Guy S and McAdam Jane who note that "According to Executive Committee Conclusion No. 81 (1997), para. (i); Executive Committee Conclusion No. 82 (1997), para. (d) (i), the UNHCR Ex Com reiterated that the principle of non-refoulement applies to asylum seekers 'whether or not they have been formally granted refugee status', and extends to 'persons in respect of whom there are substantial grounds for believing that they would be in danger of being subjected to torture, as set forth in the 1984 Convention against Torture and Other Cruel, Inhuman or Degrading Treatment or Punishment." "38

Domestic and regional courts have noted that refoulement of refugees is a violation of fundamental human rights. In the Organisation mondiale contre la torture, Association Internationale des juristes démocrates, Commission Internationale des juristes, Union interafricaine des droits de l'Homme v. Rwanda case, the African Commission on Human and Peoples' Rights in paragraph 33 stated that: "There is ample evidence in this communication that groups of Burundian refugees have been expelled on the basis of their nationality. This constitutes a clear violation of the principle of non-refoulement." 39 The African Commission on Human and Peoples' Rights found that Guinea violated Article 12 (5) that prohibits mass expulsion of non-nationals and right of non-refoulement in the Institute for Human Rights and Development in Africa (on behalf Sierra Leonean refugees in Guinea) v. Guinea 2004 case. $^{40}$

It has been argued by many scholars that the OAU Convention complements rather than duplicates the 1951 Convention. Apart from the broad refugee definition, the OAU Convention regulates the question of asylum (Article 2). It also contains important provisions on voluntary

\footnotetext{
${ }^{37} \mathrm{Ibid}$, at 3 .

${ }^{38}$ Goodwin-Gill, The Refugee in International Law, 217 (Guy S. and McAdam Jane eds., 3rd ed., Oxford, Oxford University Press, 2007).

${ }^{39}$ Organisation mondiale contre la torture, Association Internationale des juristes démocrates, Commission Internationale des juristes, Union interafricaine des droits de l'Homme v. Rwanda, 27/89-46/90-49/91-99/93, African Commission on Human and Peoples' Rights (October 1996), available at $\mathrm{http}: / / \mathrm{www}$. refworld.org/docid/51b6f4374.html (last visit May 8, 2014).

${ }^{40}$ Institute for Human Rights and Development in Africa (on behalf of Sierra Leonean refugees in Guinea) v. Guinea, 249/02, African Commission on Human and Peoples' Rights (December 2004), available at $\mathrm{http}: / / \mathrm{www}$. refworld.org/docid/51b6fc794.html (last visit May8, 2014).
} 
repatriation (Article 5) and on the prohibition of subversive activities by refugees (Article 3). Uganda acceded to the OAU Convention on 24th July 1987. Uganda therefore as a signatory to the 1969 OAU Convention has obligations to protect refugees who seek asylum on its territory.

For example, under Article II of the 1969 OAU Convention,

Member States of the OAU shall use their best endeavors consistent with their respective legislation to receive refugees and to secure the settlement of those refugees who, for well-founded reasons, are unable or unwilling to return to their country of origin or nationality.

Furthermore, Article IV of the OAU Convention obliges states to treat refugees without any discrimination. Thus,

Member States undertake to apply the provisions of this Convention to all refugees without discrimination as to race, religion, nationality, membership of a particular social group or political opinions.

Court jurisprudence in Africa shows that states are obliged to respect the right of non-discrimination. For example, the African Commission on Human and Peoples' Rights in Institute for Human Rights and Development in Africa (on behalf of Sierra Leonean refugees in Guinea) versus Guinea ${ }^{41}$ found that the respondent state of Guinea ${ }^{42}$ had violated Article IV of the OAU Convention.

States that are signatories to the OAU Convention including Uganda have obligations to receive refugees escaping persecution and insecurity and give them sanctuary with all the rights and entitlements. Other state obligations under the OAU Convention include issuing of travel documents to refugees, cooperating with UNHCR in protecting refugees and cooperating with other states in the voluntary repatriation of refugees.

However, the OAU Convention has loopholes that include among others, failure to recognize economic refugees or migrants whose socioeconomic rights are violated ${ }^{43}$, being silent as to whether victims of natural disasters can legitimately be considered as refugees ${ }^{44}$ and upholds three traditional solutions (voluntary repatriation, local integration and resettlement) that are no longer effective in addressing the contemporary

\footnotetext{
${ }^{41}$ Ibid.

${ }^{42}$ On September 9, 2000, the Guinean President Lansana Conte proclaimed over the national radio that Sierra Leonean refugees were to be arrested, searched and confined to refugee camps. His speech incited soldiers and civilians alike to engage in mass discrimination, looting, harassment and refoulement of the refugees.

${ }^{43}$ Oloka-Onyango Joe, Human Rights, The OAU Convention and the Refugee Crisis in Africa: Forty Years After Geneva, 3(3) INTERNATIONAL JOURNAL OF REFUGEE LAW 453- 460 (1991).

${ }^{44}$ Okello Moses, The 1969 OAU and the Continuing Challenge for the African Union, 48 FORCED MigRATION REVIEW 70-73 (November 2014).
} 


\section{THE LEGAL STATUS OF REFUGEE PROTECTION 743}

refugee problem. ${ }^{45}$ In other words, the Convention is yet to reflect the new trends and dynamics of forced migration in Africa.

The next section looks at national refugee law in Uganda.

\section{NATIONAL REFUGEE LAW}

\section{A. 2006 Uganda Refugees Act}

Prior to the introduction of the 2006 Uganda Refugees Act, the protection of refugees in Uganda was regulated by both International legal instruments and domestic legislation (Control of Alien Refugees Act 1960 (CARA ${ }^{46}$ but these were not always in harmony with each other. ${ }^{47}$ Overall, the Refugees Act reflects international legal standards of refugee protection provided in the 1951 Convention Relating to the Status of Refugees and its 1967 protocol and the 1969 OAU Convention Governing the Specific Aspects of the Refugee Problem in Africa. It is progressive, human rights and protection oriented. ${ }^{48}$ Although the Act has been said to be progressive and human rights focused, it contains provisions which are still hostile to refugee rights as will be discussed below. It must be noted that Uganda's domestic refugee policy is regulated by the Refugees Act of 2006 which was brought on board in furtherance of the International refugee law instruments ratified or acceded by the Uganda government.

\section{B. Refugee Rights under the Act}

The Refugees Act has a number of rights which are relevant to the refugees. For example, Section 29(e): (i) Right to movable and immovable property, (ii) right to transfer assets (iii) right to education (iv) the right to engage in agriculture, industry, handicrafts and commerce, ( $g$ ) right of association as regards non-political and non-profit making associations, (h) right to access courts of law including legal assistance under the applicable laws of Uganda, Section 32, Rights of refugee children and Section 33, Rights of women refugees.

Section 30(2) of the 2006 Uganda Refugees Act states that: "The free movement of recognized refugees in Uganda is subject to reasonable

\footnotetext{
${ }^{45}$ Oloka-Onyango Joe, Human Rights, The OAU Convention, Op. Cit.

${ }^{46}$ The Control of Aliens Refugees Act (1960) was a very draconian law hostile to refugees. The 2006 Refugees Act was a great improvement in domestic refugee legislation in Uganda.

${ }^{47}$ Refugee Law Project, Critique of the Refugees Act (2006), available at $\mathrm{http} / /$ citizenshiprightsinafrica.org/docs/Uganda_RefugeesActRLPCritique.pdf (last visit January 23 2011).

${ }^{48}$ Ibid
} 
restrictions specified in the laws of Uganda, or directions issued by the Commissioner, which apply to aliens generally in the same circumstances especially on grounds of national security, public order, public health, public morals or other protection of the rights and freedoms of others" ${ }^{49}$ In fact refugees in Uganda are required by law to get a travel permit (permission from the Settlement Commandant for refugees in settlements and Office of the Prime Minister's (OPM) for the urban refugees). The failure to do so would lead to a refugee being arrested and imprisoned.

This Act also guarantees the right of refugees to international travel documents, which are usually valid for 90 days from the date of issuance and renewable every two months. To obtain them, refugees have to apply through Office of Prime Minister and provide proof of their reasons for travel, length of stay abroad, and other travel details. Students require letters of admission; medical patients have to provide evaluations from Ugandan medical institutions explaining why no one could treat them in Uganda, those traveling to see family have to provide a letter of invitation from the family member, and business travelers have to provide proof of a legitimate business. Uganda does not provide international travel documents for asylum seekers. ${ }^{50}$ According to the Refugee Law Project, "the restriction by law is reasonable but directions issued by the Commissioner may be arbitrary. There are no detailed criteria upon which the commissioner may issue directions restricting freedom of movement". ${ }^{51}$

\section{Duties and Obligations of Refugees under the Act}

Refugee entitlements go with obligations and duties. This is the practice even with nationals/citizens who in order to enjoy rights and freedoms, have an obligation to respect certain duties and obligations. The Refugees Act in Section 35(a-f) imposes obligations on refugees if they are to continue enjoying refugee status in Uganda. Failure to observe these obligations puts the security of a refugee in jeopardy. These include:

A recognized refugee shall:

a) Be bound by and conform to all laws and regulations currently in force in Uganda;

b) Conform to measures taken for the maintenance of public order;

c) Not engage in activities which may endanger state security, harm

\footnotetext{
${ }^{49}$ Refugee Law Project, Critique of the Refugees Act, Op. Cit., at 19 (2006).

${ }^{50}$ United States Committee for Refugees and Immigrants, World Refugee Survey 2009-Uganda, (June 17, 2009), available at http://www.refworld.org/docid/4a40d2b5c.html (last visit May 23, 2013).

${ }^{51}$ Refugee Law Project, Critique of the Refugees Act, Op. Cit., at 19 (2006).
} 


\section{THE LEGAL STATUS OF REFUGEE PROTECTION 745}

public interests or disrupt public order;

d) Not engage in any political activities within Uganda, whether at local or national level;

e) Not engage in any activity contrary to the principles of the charter of the united nations and the statute of the African union and in particular, shall not undertake any political activities within Uganda against any country, including his/her country of origin;

f) If engaged in gainful employment or fully integrated and has a source of income, pay taxes in accordance with the applicable taxes of Uganda.

Some of the provisions in the Refugees act are hostile to refugee rights. For example Section 40(1) states that "The Minister may, after consultation with the Minister responsible for internal affairs, order the expulsion of any recognized refugee from Uganda, if the Minister considers the expulsion to be necessary or desirable in the interest of national security or public order". ${ }^{52}$ In cases where national security, regime security or any other perceived threat or public disorder are not clear or interpreted to serve the interests of leaders and politicians, refugee rights may be violated.

However, in a situation where refugees violate the act like engaging in violent demonstrations and rebel activities, the host state has a duty and right to ensure law and order, peace and security and defend her territorial integrity. This may necessitate the arrest, imprisonment and expulsion of refugees. The paper focuses on human rights law and refugee protection in the following section.

\section{INTERNATIONAL HUMAN RIGHTS LAW}

International refugee law is part of a larger mosaic of international human rights law and international humanitarian law. Human rights law constitutes the broad framework within which refugee law provisions should be seen. ${ }^{53}$ For example, the International Covenant on Civil and Political Rights has been interpreted to prohibit return to torture. In addition, nearly all of its provisions apply equally to non-citizens.

Refugees are entitled to two partially overlapping sets of rights: Those accorded to them as individuals and guaranteed under international human rights standards and national law, and specific rights related to their status as

\footnotetext{
${ }^{52} \mathrm{Ibid}$, at 20.

${ }^{53}$ For more discussion see Chetail Vincent, "Are Refugee Rights Human Rights? An Unorthodox Questioning of the Relations between Refugee Law and Human Rights Law" in Ruth Rubio-Marin, HumAn RightS AND IMMigRATION, at 19-72 (Oxford, Oxford University Press, 2013).
} 
refugees under refugee law. According to James Darcy "human rights standards apply to refugees and internally displaced as well; though in the case of refugees, specific provision is made by international refugee law". ${ }^{54}$ Amnesty International further argues that "Crossing an international border does not deprive asylum-seekers and refugees of their human rights and human beings have human rights, whatever label they are given and wherever they are". ${ }^{55}$ The following international human rights treaties have a particularly significant role in refugee protection and to which Uganda is a party.

\section{A. Universal Declaration of Human Rights}

The Universal Declaration of Human Rights ${ }^{56}$ (hereinafter referred to as UDHR) was adopted by the UN General Assembly in December 1948. The UDHR stresses the inherent value of human dignity and the universal nature of human rights. Although the UDHR, which comprises a broad range of rights, is not directly related to refugee law, its concepts have been reproduced in national and international legal instruments and several Constitutions, including Uganda's Constitution, have used it as the basis for a bill of rights. Surprisingly, the obligation to implement it has been more often affirmed in international human rights instruments and declarations, including but not limited to the 1993 Vienna Declaration. ${ }^{57}$

Article 3 of the UDHR provides that "everyone has a right to life, liberty and security of a person" (emphasis mine). Article 5 also states that "no one shall be subjected to torture (emphasis mine) or to cruel, inhuman or degrading treatment or punishment."

More so, Article 7 provides that

All are equal before the law and are entitled without any discrimination to equal protection of the law. All are entitled to equal protection against any discrimination in violation of this Declaration and against any incitement to such discrimination.

Article 13 states that

i) Everyone has the right to freedom of movement and residence within the borders of each State.

ii) Everyone has the right to leave any country, including his own, and to

\footnotetext{
${ }^{54}$ James Darcy, Human Rights and International Legal Standards, Op. Cit., at 14.

${ }_{55}^{5}$ Amnesty International, Rights Wherever You Are, Op. Cit., at 30 (2002).

${ }^{56} \mathrm{UN}$, Universal Declaration of Human Rights, adopted and proclaimed by the General Assembly Resolution 217A(III) of December 10 (1948).

${ }^{57}$ UN, Vienna Declaration, World Conference on Human Rights, UN Doc.A/CONF.157/24 (June 14$25,1993)$.
} 


\section{THE LEGAL STATUS OF REFUGEE PROTECTION 747}

return to his country.

Article 14 provides for everyone the right to seek and to enjoy in other countries asylum from persecution. This is relevant to refugees since they are forced to flee their own country and seek asylum in other countries. Article 26 provides for the right to education. Refugee children are entitled to education and the UDHR emphasizes the right to elementary education.

These and other rights apply to all human beings regardless of their label whether non-citizens, nationals, refugees, children, women, disabled or any social differentiations. As it is clearly evident from the provisions above, all the relevant rights mentioned above have been codified in the legally binding documents that deal with the security and protection of refugees. For example, the refugee rights spelt out in the 1951 Convention have their origins in the 1948 UDHR.

Under the preamble of the UDHR, states are called upon to protect and promote human rights for all the people under their jurisdiction. Uganda therefore has obligations of protecting, promoting and fulfilling these provisions as enshrined in the UDHR in relation to refugees living on her territory.

\section{B. International Covenant on Civil and Political Rights}

The International Covenant on Civil and Political Rights ${ }^{58}$ (hereafter ICCPR) and its protocol are the cornerstones of the human rights regime. Under Article 9(1) of the ICCPR, it is provided that everyone has a right to liberty and security of a person. In addition, Article 6 protects the inherent "right to life of every human being" and Article 7 also states "that no one shall be subjected to torture or to cruel, inhuman or degrading treatment or punishment." The Government of Uganda acceded to the ICCPR on 21 September 1996 and made a reservation to the effect that: "In respect of Articles 8 and 9: The Government of the Republic of Uganda declares that the provisions of articles 8 and 9 are recognized by it as recommendations only". ${ }^{59}$ This means that the provision in Article 9 which is a right to liberty and security of people (including refugees) is not guaranteed by the government of Uganda as mandatory but as a recommendation that does not fully bind her.

\footnotetext{
${ }^{58} \mathrm{UN}$ (1966), International Covenant on Civil and Political Rights adopted and opened for signature, ratification and accession by General Assembly resolution 2200A (XXI) of December 16, UN. Doc.A/6316 (1996), 999 U.N.T.S, entered into force March 23, 1976.

${ }^{59}$ See Reservations on ICCPR, available at http:treaties.un.org/pages/viewdetails.aspx?chapter=48=enmtdsg.nov=iv (last visit February 28, 2014).
} 
The rights enshrined in the ICCPR are obligations on states to ensure that people under their jurisdiction including refugees are able to enjoy civil and political rights. However, civil and political rights are not absolute in the case of refugees. For example, in Uganda refugees are not allowed to vote and participate in political activities. The 1951 Convention and 2006 Refugees Act prohibit refugees from engaging in the political activities of the host country. Although refugees are allowed to vote in local elections in other countries, voting rights and political participation in Uganda are reserved for citizens.

It is important to note that court decisions have confirmed that refugees are entitled to a number of rights provided for in the ICCPR, national constitutions and other human rights instruments. For example, on 18th December 2012, the Kenyan Government through the Department of Refugee Affairs issued a press release stopping the registration and reception of refugees in Nairobi. It directed all refugees to go to refugee camps. Court found that the Kenyan Government had violated the refugees' right to freedom of movement, right to human dignity and right to fair administrative action. In the case of Kituo Cha Sheria and others v. The Attorney General, in paragraph 100, the Judge ruled as follows:

I declare the Government Directive, contained in the Press Release and correspondence dated the 18th December 2012 and 16th January 2013 respectively, threatens the rights and fundamental freedoms of the petitioners and other refugees residing in urban areas and is a violation of the freedom of movement under Article 39, right to dignity under Article 28 and the right to fair and administrative action under Article 47(1) and violates the State's responsibility towards persons in vulnerable situations contrary to Article 21(3). ${ }^{60}$

\section{International Covenant on Economic, Social and Cultural Rights}

The International Covenant on Economic, Social and Cultural Rights ${ }^{61}$ (hereinafter referred to as ICESCR) was acceded to by Uganda on 21 April $1987 .{ }^{62}$ Unfortunately the ICESCR does not expressly provide for the rights of refugees. I can argue that refugees impliedly enjoy economic, social and cultural rights. According to Verdirame Guglielmo \& Harrell-Bond Barbara, "Both Kenya and Uganda are parties to the ICESCR and as a result of the

\footnotetext{
${ }^{60}$ Kituo Cha Sheria and others v. The Attorney General, Kenya: High Court, 26 July 2013, available at http://www.refworld.org/docid/51f622294.html (last visit May 28, 2014). The quoted violated rights are according to the Constitution of Kenya (Rev. 2010).

${ }^{61} \mathrm{UN}$, International Covenant on Economic, Social and Cultural Rights, Adopted and opened for signature, ratification and accession by General Assembly resolution 2200A (XXI) of December 16, 1966, entered into force January 3, 1976.

${ }^{62}$ Ibid.
} 


\section{THE LEGAL STATUS OF REFUGEE PROTECTION 749}

combined effect of the obligations deriving from it and other relevant instruments....both countries have committed themselves to protecting the economic and social rights of all human beings in the territory, including refugees". ${ }^{63}$ They further argue that "The 1951 Convention refers to specific economic and social rights to which refugees are entitled, including the right to gainful employment and education. Interestingly, the Convention also provides that refugees are to be accorded the same treatment as nationals with respect to rationing systems and public relief and assistance (arts. 20, $23)$ ". 64

Furthermore Article 11 of ICESCR provides for the right to adequate food which was also reinforced by the Committee on Economic, Social and Cultural Rights (CESCR) ${ }^{65}$ that stated that

any discrimination in access to food, as well as to means and entitlements for its procurement, on grounds of race, color, sex, language, age, religion, political or other opinion, national or social origin, property, birth or other status with the purpose or effect of impairing or nullifying the equal enjoyment or exercise of economic, social and cultural rights is a violation of International Covenant on Economic Social and Cultural Rights.

This therefore impliedly means that refugees are also granted equal rights to food just like all human beings. Any attempt aimed at denying refugees the right to food violates their fundamental entitlements as human beings.

\section{International Convention on the Elimination of All Forms of Racial Discrimination}

The International Convention on the Elimination of All Forms of Racial Discrimination ${ }^{66}$ (thereafter referred to as CERD) was adopted by the UN General Assembly in December 1965 and came into force in January 1969. Uganda acceded to CERD on 21 December $1980 .{ }^{67}$

According to Article 5(b), State parties

\footnotetext{
${ }^{63}$ Guglielmo Verdirame \& Barbara Harriell-Bond, Rights in Exile: Janus-Faced Humanitarianism, 17 STUDIES IN FORCED MigRATION 215 (New York \& Oxford, Berghahn Books, 2005).

${ }^{64} \mathrm{Ibid}$, at 215.

${ }^{65}$ Committee on Economic, Social and Cultural Rights, General Comment 12 on the right to Adequate Food (Article 11 of ICESCR) para. 8 quoted from Amnesty International, Memorandum to the Government of Uganda about the Cessation of Refugee Protection for Rwandans, Index: AFR 59/021/2011, at 12 (London, Amnesty International Publications, December 2011).

${ }^{66} \mathrm{UN}$, International Convention on the Elimination of All Forms of Racial Discrimination, adopted and opened for signature and ratification by General Assembly resolution 2106(XX), 660 U.N.T.S. 195 (1965), entered into force January 4, 1969.

${ }^{67}$ Ibid
} 
shall undertake to prohibit and to eliminate racial segregation in all its forms and to guarantee the right of everyone, without distinction as to race, color, or national or ethnic origin, to equality before the law, notably in the enjoyment of the following rights: (...) the right to security of a person and protection of state against violence and bodily harm, whether inflicted by government officials or by any individual group or institution.

However, Article 1(2) of CERD clearly stipulates that the Convention shall not apply to distinctions, exclusions, restrictions or preferences made by a state party between citizens and non-citizens. This means that relations between a state party and non citizens (refugees) are not catered for in CERD.

\section{E. Convention against Torture and Other Cruel, Inhuman or Degrading Treatment or Punishment}

The Convention against Torture and other Cruel, Inhuman or Degrading Treatment or Punishment ${ }^{68}$ (hereinafter referred to as "CAT") was adopted by the UN General Assembly in 1984 and came into force in 1987. Uganda acceded to the CAT on 26 June $1987 .{ }^{69}$ It includes a definition of torture that is in Article 1 and state parties take on extensive obligations. These include the obligation "to take measures to prevent acts of torture" (Article 2), "an obligation not to return any person to a state where there are substantial grounds for believing that he would be in danger of being subjected to torture" (Article 3) and the obligation "to establish jurisdiction over the offence of torture" (Articles $4 \& 5$ ). These articles clearly highlight state obligations towards the people living on their territories and under their jurisdiction. Refugees fall under the jurisdiction of states and live on states' territories.

It must be noted that Uganda made the following declaration to CAT on its accession:

In respect of Article 13: The Government of the Republic of Uganda reserves to itself the right to abridge this provision without recourse to courts of law or arbitral tribunals, national or international, if the Government of the Republic of Uganda deems such abridgement to be in the public interest.

This alludes to the prevention of torture or any other inhuman treatment of refugees. Courts have argued that freedom from torture

\footnotetext{
${ }^{68} \mathrm{UN}$, Convention against Torture and other Cruel, Inhuman or Degrading Treatment or Punishment, UN GAOR Supp. (No. 51) at 197, U.N.Doc.A/39/51, adopted by General Assembly Resolution 39/46 of December 10, (1984) entered into force June 26, 1987.

${ }^{69}$ Ibid.
} 


\section{THE LEGAL STATUS OF REFUGEE PROTECTION 751}

includes the respect of the principle of non-refoulement. In the case of $\mathrm{R}$ (on the application of) ABC (a minor) (Afghanistan) v. Sec'y of State for the Home Dep't and M.S.S v. Belgium and Greece, Courts have interpreted freedom from torture to include a prohibition against refoulement. ${ }^{70}$ The principle of non-refoulement prohibits any refoulement of a refugee to a country/territory where he/she has well-founded fear of persecution.

\section{F. $\quad$ Convention on the Rights of the Child}

The Convention on the Rights of the Child ${ }^{71}$ (hereafter referred to as CRC) was the first international treaty to specifically target the rights of children. It seeks to protect children from practices which particularly endanger their welfare, including economic exploitation, traffic in children, illicit use of drugs, and all forms of sexual exploitation and abuse. CRC entered into force on September 2, 1990, and has become the most widely ratified of all human rights treaties. Uganda ratified it on 16 September 1990.

Under Article 19(1), it is provided that "State Parties shall take all appropriate measures to protect the child from all forms of physical violence, injury or abuse, neglect or negligent treatment or exploitation, including sexual abuse". In addition, Article 6 states that "every child has the inherent right to life" and that State Parties shall "ensure to the maximum extent possible the survival and development of the child."

According to Article 34, State parties undertake to protect the child from all forms of sexual exploitation and sexual abuse, and in accordance with Article 37(a), "State Parties shall ensure that no child shall be subjected to torture or other cruel, inhuman or degrading treatment or punishment."

Article 22(1) of the Convention on the Rights of the Child is more specific on refugee children and states that

States Parties shall take appropriate measures to ensure that a child who is seeking refugee status or who is considered a refugee in accordance with applicable international or domestic law and procedures shall, whether unaccompanied or accompanied by his or her parents or by any other person, receive appropriate protection and humanitarian assistance in the enjoyment of applicable rights set forth in the present Convention and in other international human rights or humanitarian instruments to which said States are Parties.

Article 22(2) further states that

\footnotetext{
${ }^{70}$ See International Justice Resource Center, Asylum and Rights of Refugees, available at http://www.ijrcenter.org/refugee-law/ (last visit May 8, 2014).

${ }^{71}$ UN, Convention on the Rights of the Child, G.A. res.44/25, annex, 44 U.N.GAOR Supp. (No.49) at 167, U.N.Doc.A/44/49 (1989), entered into force September 2, 1990.
} 
For this purpose, States Parties shall provide, as they consider appropriate, co-operation in any efforts by the United Nations and other competent intergovernmental organizations or non-governmental organizations co-operating with the United Nations to protect and assist such a child and to trace the parents or other members of the family of any refugee child in order to obtain information necessary for reunification with his or her family. In cases where no parents or other members of the family can be found, the child shall be accorded the same protection as any other child permanently or temporarily deprived of his or her family environment for any reason, as set forth in the present Convention.

Paragraph 18 of the General Comment No. 6 of the Committee on the Rights of the Child states that

The principle of non-discrimination, in all its facets, applies in respect to all dealings with separated and unaccompanied children. In particular, it prohibits any discrimination on the basis of the status of a child as being unaccompanied or separated, or as being a refugee, asylum-seeker or migrant. ${ }^{72}$

\section{Paragraph 19 states that}

Article 3(1) of the CRC states that "[i]n all actions concerning children, whether undertaken by public or private social welfare institutions, courts of law, administrative authorities or legislative bodies, the best interests of the child shall be a primary consideration". In the case of a displaced child, the principle must be respected during all stages of the displacement cycle. At any of these stages, a best interest's determination must be documented in preparation of any decision fundamentally impacting on the unaccompanied or separated child's life. $^{73}$

It is interesting to observe how courts have dealt with refugee children's rights. Four jurisprudence cases are particularly relevant: Lukwago v. Ashcroft, Attorney General ${ }^{74}$, ZH (Tanzania) v. Secretary of State for Home Department, ${ }^{75}$ ST (Child asylum seekers) Sri Lanka v. Secretary of State for the Home Department and Suppiah \& Ors, R (on the application of) v. Secretary of State for the Home Department. In the Lukwago v Ashcroft, Attorney General Case, court argued that former child soldiers who had escaped the Lord's Resistance Army captivity may

\footnotetext{
${ }^{72}$ Committee on the Rights of the Child (2005), Treatment of Unaccompanied and Separated Children outside their Country of Origin, General Comment No. 6: 7-8, Session 39, May 17-June 3, available at http://www2.ohchr.org/english/bodies/crc/docs/GC6.pdf (last visit May 26, 2014).

${ }^{73} \mathrm{Ibid}$, at 8.

${ }^{74}$ Lukwago v. Ashcroft, Attorney General, No. 02-1812, 14 May 2003 (US Court of Appeals for the 3rd Circuit), available at http://www.refworld.org/docid/47a7078c3.html (last visit May 25, 2014).

${ }^{75} \mathrm{ZH}$ (Tanzania) (FC) (Appellant) v. Secretary of State for the Home Department (Respondent), UKSC 4, United Kingdom: Supreme Court, February 1, 2011, available at http://www.refworld.org/docid/4d5aa24212.html (last visit May 25, 2014).
} 


\section{THE LEGAL STATUS OF REFUGEE PROTECTION 753}

constitute a particular social group. "It fits precisely within the recognition that a shared past experience may be enough to link members of a particular social group". ${ }^{76}$ It is important to note that the court's declaration on a former child soldier (Lukwago Bernard) sets a precedent that persecuted children constitute a particular social group and qualify for refugee status and protection. In the case of ZH (Tanzania) v. Secretary of State for Home Department, court ruled that the interests of the child should always be respected. This ruling has had great influence on immigration, asylum and refugee cases that involve children. In the case of ST (Child asylum seekers) Sri Lanka v. Secretary of State for the Home Department paragraph 65, the judges argued that

We accept that where a child or young person has a well-founded fear of being trafficked or exposed to sexual abuse, this is a form of serious harm sufficient to engage international protection and can be evidence of a fear of persecution for a Convention reason: Usually membership of a particular social group, vulnerable to such form of harm. ${ }^{77}$

The judges over turned the previous court decision that had denied the child refugee status and argued that persecuted children constitute a "social group" as provided for under the 1951 UN Refugee Convention. Court was in favor of granting refugee status to the Sri Lankan child asylum seeker. In the case of Suppiah \& Ors, R (on the application of) v. Secretary of State for the Home Department, UK, the two children failed asylum seekers with their families had been arrested and detained by the UK Border Agency in 2010. The High Court of Justice argued that, thus,

The judge held that the decision-makers failed to have regard to their duty to safeguard and promote the welfare of the child claimants (as required by section 55 of the 2009 Act) in advance of their decision to detain them, and therefore their detention was unlawful. The authorization of detention of the claimants was in direct conflict with the Policy, which demanded that the decision-maker should have regard to section 55 of the 2009 Act, consider all reasonable alternatives to detention and resort to detention only as a measure of last resort and in exceptional circumstances. With respect to the $\mathrm{ECHR}^{78}$ claims, the judge found a breach of Article 5 as the detention of the claimants was arbitrary, and a breach of Article 8 as the unlawful detention itself constituted an unacceptable

\footnotetext{
${ }^{76} \mathrm{UNHCR}$, UNHCR Compilation of Case Law on Refugee Protection in International Law, at 1617 (March, 2008), available at http://www.refworld.org/pdfid/47dfc8e32.pdf (last visit April 20, 2014).

${ }^{77}$ ST (Child asylum seekers) Sri Lanka v. Secretary of State for the Home Department, UKUT 00292 (IAC), United Kingdom: Upper Tribunal (Immigration and Asylum Chamber) (May 31, 2013), available at $\mathrm{http} / / / \mathrm{www}$. refworld.org/docid/51d2d7184.html (last visit May 25, 2014).

${ }^{78}$ Council of Europe (1950), European Convention for the Protection of Human Rights and Fundamental Freedoms, as amended by Protocols Nos. 11 \& 14.
} 
infringement of their right to private life. ${ }^{79}$

Uganda therefore has obligations to protect rights of refugee children including rights to life, freedom from torture or other cruel, inhuman or degrading treatment or punishment, sexual abuse, discrimination and security of person.

\section{G. Convention on Elimination of All Forms of Discrimination against} Women

The Convention on Elimination of All Forms of Discrimination against Women ${ }^{80}$ (hereafter referred to as CEDAW) was adopted in December 1979 and entered into force two years later. ${ }^{81}$ It is today, one of the most ratified international human rights instruments. Uganda ratified CEDAW on 21st August 1985.

Much as it does not directly provide for the security of refugees, it can impliedly be concluded that women refugees must be accorded the same protection as men and to this end, there must be no discrimination of women refugees on the basis of their sex. Uganda as a signatory to this convention has obligations to eliminate, fight against, legislate and put measures in place to stop discrimination against women including refugee women. Courts have pronounced themselves on the issue of women's rights. Three cases are discussed hereunder to illustrate the rights of refugee women.

First is the case of In re Fauziya Kasinga ${ }^{82}$, the US Executive Office for Immigration Review Board of Immigration Appeals reached the conclusion that

(1) The practice of female genital mutilation ${ }^{83}$, which results in permanent disfiguration and poses a risk of serious, potentially life-threatening complications, can be the basis for a claim of persecution.

(2) Young women who are members of the Tchamba-Kunsuntu Tribe of

\footnotetext{
${ }^{79}$ Suppiah \& Ors, R (on the application of) v. Secretary of State for the Home Department, quoted by Child Rights International Network, Legal Database: Suppiah \& Ors, R (on the application of) v.

Secretary of State for the Home Department (January 11, 2011), available at https://www.crin.org/en/library/legal-database/suppiah-ors-r-application-v-secretary-state-homedepartment. (last visit May 27, 2014).

${ }^{80}$ UN (1979), Convention on Elimination of All Forms of Discrimination against Women, G.A.res.34/180,34 U.N. GAOR Supp. (No.46) at 193, U.N.Doc.A/34/46, entered into force September 3, 1981.

${ }^{81}$ See more on http://www.unhcr.org/4371d8362.pdf.

${ }^{82}$ In re Fauziya Kasinga, 3278, United States Board of Immigration Appeals (June 13, 1996), available at $\mathrm{http}: / / \mathrm{www}$. refworld.org/docid/47bb00782.html (last visit May 26, 2014).

${ }^{83}$ Article 2 of CEDAW states the duty of the state to ensure the elimination of discrimination in laws, policies and practices nationally. Article 5 obliges states to abolish discriminatory cultural practices or traditions against women.
} 


\section{THE LEGAL STATUS OF REFUGEE PROTECTION 755}

northern Togo who have not been subjected to female genital mutilation, as practiced by that tribe, and who oppose the practice, are recognized as members of a 'particular social group' within the definition of the term 'refugee' under section 101(a)(42)(A) of the Immigration and Nationality Act, 8U.S.C. \& 1101(a)(42)(A) (1994).

(3)The applicant has met her burden of proving through credible testimony and supporting documentary evidence (1) that a reasonable person in her circumstances would fear country-wide persecution in Togo on account of her membership in a recognized social group \& (2) that a favorable exercise of discretion required for a grant of asylum is warranted.

Secondly, is the case of Islam (A.P.) v. Secretary of State for the Home Department; Regina v. Immigration Tribunal and Another Ex Parte Shah (A.P.), (1999). Thus

In the joined cases, Islam (A. P.) v. Secretary of State for the Home Department; Regina v. Immigration Tribunal and Another Ex Parte Shah (A. P.), (1999) (H.L.) (appeal taken from England) (U.K.), the U.K. House of Lords held that women in Pakistan constituted a social group, granting asylum to two women from Pakistan who had fled domestic violence. $C f$., Matter of R-A-, 22 I \& N 906 (BIA 1999) (denying asylum to woman claiming membership in social group identified as "Guatemalan women who have been intimately involved with Guatemalan male companions, who believe women are to live under male domination"). According to the House of Lords, whether such a broad definition of a social group qualifies under the Convention will depend on evidence of how that group is treated in the country of nationality or habitual residence at issue. Id. (citing In Re G. J. (1998) 1 N.Z.L.R. 387 (New Zealand Refugee Status Appeals Authority), a New Zealand decision granting asylum on the basis of membership in a particular social group to a homosexual from Iran). ${ }^{84}$

The third case is TB (PSG-Women) Iran v. Secretary of State for the Home Department ${ }^{85}$. Thus

In 2005, the Immigration Appeal Tribunal in UK found that 'young Iranian women who refuse to enter into arranged marriages constitute a particular social group and that the woman involved was at risk of persecution due to a failure of state protection. The woman involved in the case had been at risk of serious physical abuse or even murder by her father because she opposed her forced marriage to a man much older than herself. ${ }^{86}$

\footnotetext{
${ }^{84}$ International Justice Resource Center, Asylum and Rights of Refugees, available at http://www.ijrcenter.org/refugee-law/ (last visit May 26, 2014).

${ }^{85}$ TB (PSG-Women) Iran v. Secretary of State for the Home Department, UKIAT 00065, United Kingdom: Asylum and Immigration Tribunal/Immigration Appellate Authority (9 March 2005), available at http://www.refworld.org/docid/423eaf264.html (last visit May 26, 2014).

${ }^{86}$ Kamena Dorling, Marchu Girma \& Natasha Walter, Refused: The Experiences of Women Denied Asylum in the UK, at 20 (May 2012), available at $\mathrm{http} / / / \mathrm{www}$. refugeewomen.com/images/refused.pdf (last visit May 24, 2014).
} 
This Iranian woman was granted refugee status in the UK due to persecution on the basis of belonging to "a particular social group of women" that had refused arranged marriages in Iran. The above cases illustrate the courts' jurisprudence on refugee women and asylum seekers. I can conclude that refugee women are entitled to rights as provided for under CEDAW and other refugee and human rights laws.

\section{H. African (Banjul) Charter of Human and Peoples' Rights}

The African Charter of Human and Peoples' Rights ${ }^{87}$ (hereafter referred to as "African Charter") was adopted by the Session 18, of the Assembly of Heads of State and Government of the OAU in June $1981{ }^{88}$ The African Charter entered into force on October 21st, 1986 and Uganda ratified it on May 10th, 1986. It was the 28th country to ratify the African Charter.

Under Article 4 of the African Charter, "human beings are inviolable and every human being shall be entitled to respect for his life and the integrity of his or her person. No one may be arbitrarily deprived of this right".

Article 5 further states that "every individual shall have the right to the respect of the dignity inherent in a human being and that also all forms of exploitation or degradation of man, particularly torture, cruel, inhuman and degrading punishment and treatment shall be prohibited".

Article 6 of the African Charter guarantees the right of every individual to liberty and to the security (emphasis mine) of a person. It should be noted that the above rights are also to be accorded to refugees since they are also persons.

States that are party to the African Charter have obligations to guarantee these rights. According to the preamble of the African Charter,

The State parties to the African Charter are under an obligation to recognize the rights, duties and freedoms contained in the Charter and to adopt legislative or other measures to give effect to them. They shall have the duty to promote and ensure through teaching, education and publication, the respect of the following rights and freedoms.

\footnotetext{
${ }^{87}$ OAU (1981), African (Banjul) Charter of Human and People's Rights, OAU Doc.CAB/LEG/67/3 rev.5, 21 I.L.M. 58 (1982), adopted June 27, entered into force on October 2, 1986.

${ }^{88}$ Anika Andreevska \& Emelie Roos, Finding Durable Solutions or Simply Putting Refugee Protection to an End? An Examination of Uganda's Obligations when Ending Protection for the Rwandan Refugees, (LLM Thesis, Unpublished, University of Gothenburg, Autumn 2011). Available at Göteborgs Universitet/Anika o Emelie.pdf.

${ }^{89}$ See Human Rights Education Associates, University of Minnesota, Study Guide: The Rights of Refugees (2003), available at http://www1.umn.edu/humanrts/edumat/studyguides/refugees.htm.
} 


\section{THE LEGAL STATUS OF REFUGEE PROTECTION 757}

The African Commission on Human and Peoples' Rights in Institute for Human Rights and Development in Africa (on behalf of Sierra Leonean refugees in Guinea) versus Guinea ${ }^{90}$ found that the respondent state of Guinea had violated Articles 2 (Freedom from discrimination), 4 (Right to life and integrity of person), 5 (Right to inherent dignity and freedom from all forms of exploitation and degradation), 12(5) (Prohibition of Mass expulsion of non-nationals) and 14 (Right to property) of the African Charter. This case illustrates the fact that refugees are entitled to the rights enshrined in the African Charter and State Parties have obligations to respect, protect and fulfill these rights. The African Commission on Human and Peoples' Rights came to the same conclusion in the case of the Organisation mondiale contre la torture, Association Internationale des juristes démocrates, Commission Internationale des juristes, Union inter africaine des droits de l'Homme v. Rwanda. ${ }^{91}$ The Commission argued that by expelling Burundian refugees, Rwanda's actions had caused violations of the Charter, namely of Articles 4, 5, 6, 7(1), 12(3), 23(4), and 12(5). ${ }^{92}$

\section{I. $\quad$ African Charter on Rights and Welfare of the Child}

The African Charter on Rights and Welfare of the Child ${ }^{93}$ (hereinafter referred to as "ACRWC") was adopted by OAU at the Session 26 of the Assembly of Heads of States and governments in July 1990 and it entered into force on November 29, 1999. Uganda ratified ACRWC on August 17, 2004. It must be noted that the wording of ACWRC is similar to the one of CRC.

However the Children's Charter originated because the member states of the African Union believed that the CRC missed important socio-cultural and economic realities particular to Africa and the ACRWC emphasizes the need to include African cultural values and experiences when dealing with the rights of the child, thus challenging traditional African views which often conflict with children's rights such as child marriage, parental rights and obligations towards their children, and children born out of wedlock.

Article 5 of the ACWRC acknowledges that "every child has an

\footnotetext{
${ }^{90}$ Institute for Human Rights and Development in Africa (on behalf of Sierra Leonean refugees in Guinea) v. Guinea, 249/02, Op. Cit.

${ }^{91}$ Organisation mondiale contre la torture, Association Internationale des juristes démocrates, Commission Internationale des juristes, Union interafricaine des droits de l'Homme v. Rwanda, $O p$. Cit.

${ }^{93}$ OAU, African Charter on the Rights and Welfare of the Child (1981), OAU Doc.CAB/LEG/24.9/49 (1990), adopted on June 27, entered into force on November 29, 1999.
} 
inherent right to life" and Articles 5(1) and 28 stipulate that "children shall be protected against child abuse and torture as well as against sexual exploitation". It should be noted that refugee children are also protected by this Charter and Uganda has obligations of protecting the lives and security of refugee children living on its territory.

Article 23(1) of the ACRWC states that

States Parties to the present Charter shall take all appropriate measures to ensure that a child who is seeking refugee status or who is considered a refugee in accordance with applicable international or domestic law shall, whether unaccompanied or accompanied by parents, legal guardians or close relatives, receive appropriate protection and humanitarian assistance in the enjoyment of the rights set out in this Charter and other international human rights and humanitarian instruments to which the States are Parties.

Goodwin Gill, a refugee law jurist argues that

the legal responsibility for unaccompanied refugee children rests with the government of the country of asylum. An unaccompanied child should have a legal guardian with respect to involvement in any legal proceedings and may need a legal guardian to advocate for the child's interests or to make decisions on behalf of the child in other situations. ${ }^{94}$

In the case of Abdulahi and others v. The Minister of Home Affairs and others, Interim Order of 24 May 2011 and pleadings ${ }^{95}$ the High Court in South Africa ordered as a matter of urgency the consideration for the Somali child's application for asylum. The court's order was in the best interest of the child as provided for under human rights law. In Paragraph 2, the Court ordered the Minister of Home Affairs and The Tshwane Interim Refugee Reception Centre "to issue the First Applicant (Abdulahi Shaafi) with a Section 22 asylum seeker permit pending the final determination of and finalization of the main application and for purposes of this application only". ${ }^{96}$ Court argued that it was difficult for this child asylum seeker to enjoy his rights without any documentation/asylum permit. This case illustrated the need to protect the rights of children asylum seekers as provided for under refugee and human rights law.

\footnotetext{
${ }^{94}$ Goodwin-Gill G, Children on the Move: How to Implement Their Right to Family Life, Protecting the Human Rights of Refugee Children and Some Legal and Institutional Possibilities. Martinus Nijhoff Publishers, at 97-100 (1996), Quoted by Anthea van der Burg, Legal Protection of Undocumented Foreign Migrant Children in South Africa: Reality or Myth?, Law, Democracy and Development, at 86 (2009), available at http://www.saflii.org/za/journals/LDD/2006/12.pdf (last visit May 26, 2013).

${ }_{95}$ Abdulahi and others v The Minister of Home Affairs and others, Interim Order of 24 May 2011 and pleadings, 26572/2011, South Africa: High Court (24 May 2011), available at http://www.refworld.org/docid/5177bfcb5.html (last visit May 26, 2014).

${ }^{96} \mathrm{Ibid}$, at 2.
} 


\section{THE LEGAL STATUS OF REFUGEE PROTECTION 759}

Furthermore, in the case of Institute for Human Rights and Development in Africa (IHRDA) and Open Society Justice Initiative (on behalf of Children of Nubian Descent in Kenya) v. the Government of Kenya $^{97}$, the African Committee of Experts on the Rights and Welfare of the Child (ACERWC) found that Kenya had violated the rights of Nubian children contrary to the African Charter on Rights and Welfare of the Child. In paragraph 69 "the African Committee finds multiple violations of Articles 6(2), (3) and (4); Article 3; Article 14(2) (b), (c) and (g); and Article 11(3) of the African Children's Charter by the Government of Kenya". ${ }^{98}$ Among these multiple violations included: Freedom from unfair/unlawful discrimination and consequential violations of right to equal access to education and health care. ${ }^{99}$ Although this case did not address directly the rights of refugees and asylum seekers, it will continue to have influence on the jurisprudence of Children's rights including refugee children in Africa.

\section{J. Protocol to the African Charter on Human and Peoples' Rights on the Rights of Women in Africa}

The Protocol to the African Charter on Human and Peoples' Rights on the Rights of Women in Africa (better known and hereinafter referred to as "Maputo Protocol") was adopted by the African Union on 11 July 2003 at its second summit in Maputo, Mozambique and it entered into force in November 2005. Uganda ratified the Maputo Protocol on July 22, 2010.

Under Article 3(1) of the Maputo Protocol, "every woman shall have the right to dignity inherent in a human being and to the recognition and protection of her human and legal rights." Article 4(1) further provides that "every woman shall be entitled to respect for her life and the integrity and security of her person."

It should be noted that the above rights are also to be accorded to refugee women since they are also human beings. Uganda therefore has obligations under the Maputo Protocol of protecting refugee women against all forms of violence, abuse and human rights violations. Court decisions

\footnotetext{
${ }^{97}$ Institute for Human Rights and Development in Africa (IHRDA) and Open Society Justice Initiative (on behalf of Children of Nubian Descent in Kenya) v. the Government of Kenya, Decision No 002/Com/002/2009, African Committee of Experts on the Rights and Welfare of the Child (ACERWC) (22 March 2011), available at http://www.refworld.org/docid/4f5f04492.html (last visit May 27, 2014).

${ }^{98}$ Institute for Human Rights and Development in Africa (IHRDA) and Open Society Justice Initiative (on behalf of Children of Nubian Descent in Kenya) v. the Government of Kenya, ibid. ${ }^{99}$ Institute for Human Rights and Development in Africa (IHRDA) and Open Society Justice Initiative (on behalf of Children of Nubian Descent in Kenya) v. the Government of Kenya, ibid.
} 
point to the significance of refugee women's rights. For example in the case of Union of Refugee Women and Others v Director: Private Security Industry Regulatory Authority and Others ${ }^{100}$ court argued that denying employment to refugee women in the South African private security industry was discrimination against them. The Private Security Industry Regulation Act 56 of 2001 (the Security Act) requires security service providers to register with the Private Security Industry Regulatory Authority (the Authority). Section 23(1) (a) of the Security Act lists citizenship or permanent residence as a requirement for registration. The applicants (refugee women and others) challenged Section 23(1)(a) that it discriminated against them on the basis that they were not citizens or permanent residents. ${ }^{101}$

The judge in the Constitutional Court argued in Paragraph 147 that "I see no reason why access to employment in the security industry by persons in their situation should not be permitted in relation to sectors such as these, where no high security interests are at stake. To bar them would be to discriminate against them unfairly". ${ }^{102}$ This court ruling emphasizes the right of employment ${ }^{103}$ for refugee women and all refugees. The ruling also points to the right of non-discrimination ${ }^{104}$ for refugee women and other refugees. The paper turns to national human rights law in the next section.

\section{NATIONAL HUMAN RightS LAW}

\section{A. 1995 Uganda Constitution}

The Constitution of the Republic of Uganda as amended in 2005 recognizes the importance of human rights and requires the state to ensure that rights of human beings are respected and protected at all times. Article 20(1) states that "fundamental rights and freedoms of individuals are inherent and not granted by the state". ${ }^{105}$ This therefore means that by the mere fact that one exists as a human being, one is entitled to the enjoyment

\footnotetext{
${ }^{100}$ Union of Refugee Women and Others v. Director: Private Security Industry Regulatory Authority and Others, Case CCT 39/06, South Africa: Constitutional Court, 12 December 2006, available at http://www.refworld.org/docid/502391602.html (last visit May 25, 2014).

${ }^{101} \mathrm{Ibid}$, at $1-5$.

${ }^{102} \mathrm{Ibid}$, at 180.

${ }^{103}$ Article 13 of the Maputo Protocol states that "state parties shall adopt and enforce legislative and other measures to guarantee women equal opportunities in work and career advancement and other economic opportunities", Article 17 of the 1951 UN Refugee Convention spells out the refugees' right to wage earning employment.

${ }^{104}$ Article 3 of the Maputo Protocol provides for elimination of discrimination against women.

105 The 1995 Constitution of the Republic of Uganda.
} 


\section{THE LEGAL STATUS OF REFUGEE PROTECTION 761}

of fundamental rights and freedoms.

Article 21(1) further states that "all persons are equal before and under the law in all spheres of political, social and cultural life and in every other respect and shall enjoy equal protection of the law". ${ }^{106}$ This article also includes refugees since it talks of "all persons" and refugees are also "persons." The state is therefore under an obligation to ensure that all persons including refugees under its jurisdiction enjoy the right to security. Refugees are thus entitled to legal protection under the Constitution of Republic of Uganda.

The Uganda Constitution also includes a Bill of Rights enshrining civil and political rights, economic, social, and cultural rights. "Rights holders are defined as 'all persons' or 'every person' in Uganda thereby unequivocally including refugees". ${ }^{107}$ Article 286 of the Constitution provides that treaties already in force before the Constitution are not affected. This means that all provisions regarding security and rights of refugees embedded in international instruments existing before the coming into force of the Constitution continue to bind Uganda.

Court judgments have illustrated that constitutional rights extend to refugees. ${ }^{108}$ For example, in December 2012, the directive by the Kenyan Government to relocate all urban refugees from Nairobi to the refugee camps of Kakuma and Dadaab violated constitutional rights of refugees. In the case of Kituo Cha Sheria and others v. The Attorney General, in paragraph 97, the Judge ruled that "It is the duty of the State to come up with a system of registration of refugees that is consistent with the principles and values of the Constitution as I have endeavored to outline in this judgment. The State has a wide scope to design and implement policies that respect the tenets of the Constitution and it must now go back to the drawing board". 109

\section{B. The Children's Act}

It must be noted that the Ugandan Children's Act, Chapter 59, Laws of Uganda derives its inspiration and consequential force from CRC and ACRWC. It was adopted on August 1, 1997. Under this Act, Local Councils (LCs) are responsible for child protection (Section 190). Section 13 provides

\footnotetext{
${ }^{106}$ Ibid.

${ }^{107}$ Guglielmo Verdirame \& Barbara Harriell-Bond, Rights in Exile: Janus-Faced Humanitarianism, Op. Cit., at 28.

${ }^{108}$ Not all constitutional rights extend to refugees. For example refugees do not have a right to vote since they are not citizens. This right is specifically for citizens of the host country.

${ }^{109}$ Kituo Cha Sheria and others v. The Attorney General, Op. Cit.
} 
that if these local government councils cannot resolve a child protection case, it is brought before the family and children court. Section 16 provides that "the child shall have a right to legal representation" in all matters before the family and children court. The Act does not provide any additional information about the responsibilities or duties of the legal representative for the child, nor is the family and children court funded by the government. Representing children who have been abused or neglected is primarily the responsibility of the state, which would prosecute these cases in criminal proceedings.

Thus it seems that most child abuse and neglect cases are handled through the criminal system, whereas most civil family law cases concern maintenance and custody proceedings. From the wording embedded in the Act i.e. "the child...." one can safely argue that "the child" includes the children in refugee camps. Since the Children's Act talks about protection of all the children as a right not a privilege, it can be safely concluded that refugee children in Uganda are equally entitled to this protection.

\section{CONCLUSION}

As discussed above, Uganda has hosted refugees from neighboring countries since the Second World War to date. Since Uganda is situated in a turbulent Great Lakes region, she will continue to host refugees fleeing conflicts and wars from the countries of origin. Uganda has been praised for her "open door" response to refugees. Overall Uganda's 2006 Refugees Act is a progressive law that protects refugee rights and reflects its national, regional and international obligations. However, it contains some provisions which restrict refugee rights. Uganda is a signatory to refugee and human rights legal treaties that protect refugees. Refugee law protects refugees by virtue of their status as people outside their countries of origin and in need of international protection. Specifically the 1951 Refugee Convention spells out "a bill of refugee rights" which has been replicated in Uganda's domestic refugee law. Refugees are also protected by human rights law by virtue of the fact that they are human beings regardless of the label they are given as refugees.

The decisions of national courts, African Commission on Human and Peoples' Rights, other regional courts and judicial bodies and United Nations Treaty Committees have shown that refugees are protected by human rights law. The paper has also identified gaps in refugee and human rights law which may compromise the protection of refugees and the responsibilities of states. It is recommended that Uganda needs to address 


\section{THE LEGAL STATUS OF REFUGEE PROTECTION 763}

the gaps within her domestic refugee law through appropriate amendments. The United Nations and African Union should amend the 1951 Convention and 1969 OAU Convention respectively to reflect the new trends and dynamics of forced displacement in the contemporary world and Africa in particular. This will give state parties to the conventions the enabling legal frameworks to protect refugees on their territories. 